\title{
Mapping Factors Supporting Social Integration of the Minangkabau Community in Luhak Tanah Datar
}

\author{
Maryam Lamadirisi* \\ Fakultas Ilmu Sosial \\ Universitas Negeri Manado \\ Manado, Indonesia \\ maryamlamadirisi@yahoo.co.id
}

\author{
Siti Fathimah \\ Fakultas Ilmu Sosial \\ Universitas negeri Manado \\ Manado, Indonesia \\ sitifathimah@unima.ac.id
}

\author{
Sangputri Sidik \\ Fakultas Ilmu Sosial \\ Universitas negeri Manado \\ Manado, Indonesia \\ putrisidik@unima.ac.id
}

\begin{abstract}
Luhak Tanah Datar is one of the luhak which is the area of natural origin of the Minangkabau as well as a cultural center known as Luhak Nan Tigo. Like other luhak, this luhak also has very thick cultural values. This study aims to describe local elements in terms of sociocultural factors that are potential supporters of social integration in the Minangkabau community in Luhak Tanah Datar, West Sumatra. This research is a descriptive study with a qualitative approach. The research informants were elements of regional leadership (wali nagari), elements of youth, elements of traditional leaders, elements of religious leaders, and ordinary people (immigrants and indigenous people). The data collection techniques used were observation, interview, and documentation study. The findings in this study are that the socio-cultural elements in the Minangkabau community in Luhak Tanah Datar that can unite the community to create social integration are located in the conventional philosophical system based on the teachings of Islam, language, art, kinship system, and customs, which still strong in people's lives. Also, the maintenance of cultural elements that are still strong and make the community still exist with their customary philosophy, namely the custom of basandi syara ', syara' basandi Kitabbullah, and this becomes a guideline for every community in society so that the conditions of harmonious neighbors are neatly woven.
\end{abstract}

Keywords: social integration, luhak, Minangkabau

\section{INTRODUCTION}

There are many writings on conflict resolution or even things that can strengthen social solidarity to grow social integration in society. Reference [1] for one, in an article entitled Workplace conflict resolution in Wales: The unexpected prevalence of alternative dispute resolution, discusses Alternative Dispute Resolution (ADR) or alternative dispute resolution in resolving conflicts in the workplace as a strategy to overcome various problems. Form of conflict with Welsh companies in the UK. This article discusses one of the conflict resolutions, namely the application of ADR (alternative dispute resolution), where dispute resolution can not only be resolved through law, but through modified mediation, so the conflict that occurs does not take time and costs expensive and after conflict resolution. Disputing parties can forgive each other and establish a productive relationship again.

Reference [2] with the title The Interdependence Of Conflict Management Attempts, which discusses the efforts of dependent conflict management. She was looking at the history of conflict and its resolution to prevent future conflicts. Diehl \& Regan's research states that what happened before (conflict) influences the present and future events. Most of this research, however, focuses only on escalators dynamics in military contests, or on structural changes to influence outcomes. This paper examines the interdependence of conflicts, actors, techniques, space, and time. For this reason, senior officials need to consider this element in trying to explain conflict resolution to policymakers. In his writing, Diehl $\&$ Regan discusses one of the resolutions in conflict resolution, which emphasizes conflict resolution by combining past conflict events, including how to resolve them at that time and linking them (spatial and temporal aspects) to current conflicts to help resolve conflicts. on an integrated basis.

In contrast to reference [3], in her writing entitled Law Awareness Forming Strategies to Reinforce, The Principles of Social Function of Land Rights Within The Moral Dimension of Citizenship discusses conflicts and their solutions to the people of Jakarta. Nationality issues often create conflicts of interest that affect land conflicts. The results of the study explained that community awareness of land laws was still low so that it could lead to conflict. The law of awareness forms a strategy to strengthen the social principles of land use in the moral dimension of citizenship by using the method of internalizing values such as responsibility, patriotism as an agrarian society, solidarity in social life, and the priority of working together in land use.

In his writing, Triana Rejekiningsih explains the strategy for dealing with citizenship issues related to land, namely by the cultivation of ethical, moral values, which can be socialized through moral education and values can reform good behavior to use the land for public purposes as a principle of the social function of land rights. Triana Rejekiningsih revealed about land conflicts caused by the lack of awareness and knowledge of the community regarding land law and the resolution of these conflicts through education and internalization of citizenship values.

Meanwhile, reference [4] with the title The Effect of Sociopsychological Barriers on the Processing of New Information about Peace Opportunities, which discusses how sociopsychology can prevent conflict resolution in 
Israel. Community members develop a social psychological infrastructure that leads to information filtering, which prevents the dissemination of new information that can facilitate peace. This research questions sociopsychological barriers to resolving conflicts peacefully: what are the nature of these barriers, and how do they function? In his writing, he explains how to resolve conflicts, where to resolve conflicts, the first focus that must be addressed is the community's framework of thinking about conflict, by finding ways to overcome sociopsychological barriers, to encourage community members involved in violent conflict to consider it peacefully.

Likewise with reference [5] with the title Protected by Ethos in a Protracted Conflict? A Comparative Study among Israelis and Palestinians in the West Bank, Gaza, and East Jerusalem, which discusses the prolonged conflict in Israel-Palestine to foster an ethos of conflict which is considered capable of abating conflict, as well as triggering conflict, where when hit by violent events, people with a great ethos may believe that they are part of a nation that has faced hardships for centuries and thus has the stamina to continue or resolve conflicts. Thus, the prolonged conflict in Israel-Palestine resulted in the emergence of a conflict ethos that was able to obstruct peace between the two warring parties.

Reference [6], in his article entitled Conflict Resolution to Project Performance, this article discusses how the main strategies in solving conflict problems, by considering different sources of conflict. This is due to globalization worldwide, resulting in more multicultural and multidisciplinary, forcing Project Managers (PM) to combine and align the interests of various stakeholders while keeping in mind different points of view and having to deal with conflicts of different origins. The way to overcome this is by providing education and learning experiences so that each in the future can control conflict. By this, we are aware of the importance of implementing additional components in a teaching plan, correctly oriented to help lead students to have a better understanding of the different conflict management strategies as well as the sources of conflict causes.

Also, in their writings, [7] explain that art is one of the various ethnic unifying tools, for example when a Bugis art stage is held, it is often attended by heads of other ethnic associations, such as the chairman of the Banjar, Melayu, Minangkabau associations, Etc. People from other ethnic communities are also willing to become committees and help carry out these art activities so that they run smoothly. By establishing cooperation and complementing each other, a harmonious unity is formed and can foster community integration.

Likewise, reference [8], in her writing entitled Religion, Conflict, and Social Integration (Post-Situbondo Social Integration), found the same thing in the Situbondo Society, namely integration and reconciliation efforts have been carried out by the community and religious communities in Situbodo. One of the efforts to deal with conflict is to hold regular meetings and gatherings by Priest, and Kiai, in order to discuss issues surrounding religious life. Furthermore, joint steps were also taken to make a peace agreement and humanitarian cooperation.

The same thing is also found in reference [9] writing that the habit of deliberation and consensus and nagari (with the enactment of regional autonomy Law of the Republic of Indonesia No. 23/2014 on Regional Government) as a forum for resolving community problems can reduce and resolve existing conflicts. So that society is integrated back into a conducive condition. Likewise, in his writings on the mapping of social integration in the Fifty Cities luhak, where local people work hand in hand in doing good even though these residents are not native residents of the area.

Based on the findings above, several ways or factors can be used to strengthen the social integration of a society, from how to resolve conflicts to cultural values that can strengthen solidarity among fellow communities to create social integration in that society. Likewise, with the Minangkabau community based on tambo, the area of the natural origin of the Minangkabau is divided into three luhak known as Luhak Nan Tigo. As the heart of the Minangkabau area, this region is undoubtedly the cultural center of the Minangkabau community. Luhak Tanah Datar is one of them or administratively called Tanah Datar Regency.

As the cultural center of the Minangkabau community, this luhak certainly has functional and robust customs to unite its people; besides that, the diversity of the local community is also undeniably able to cause friction of the flames of conflict. However, unlike other areas in Indonesia, the Minangkabau people, especially the people in Luhak Tanah Datar, are relatively conducive and far from issues of division, even though conflicts cannot be eliminated but can be minimized so that the conflicts that occur do not last a long time. This is what attracts the writer to map the supporting factors that can make the Minangkbau community in Luhak Tanah Datar integrated and able to live side by side with other communities of different ethnicity, religion, and other customs.

\section{RESEARCH METHOD}

This research uses a descriptive qualitative approach. The location of the research was carried out in one of the Minangkabau Nature areas, namely Luhak Tanah Datar. Furthermore, from this luhak, the Tigo Koto village was selected to be used as a research location purposively with the characteristics of the village, which had high heterogeneity both in terms of ethnicity or religion and which was still thick with Minangkabau customs. In this study, the selection of informants was carried out on purpose (purposive sampling). In general, the types of data used in research are primary and secondary data. Techniques used in data collection in this study are carried out through observation, interviews, and documentation studies.

\section{RESULTS AND DISCUSSION}

\section{A. Results}

Based on data obtained from the Tanah Datar Central Statistics Agency in 2017 figures, Tanah Datar district is 
located at 00017 'and 000 39' south latitude and between 100019 '- 1000 51' east longitude. Tanah Datar Regency has an area of $1,336 \mathrm{~km}^{2}$, consisting of 14 Districts and 75 Nagari (every sub-district in the city area). Tanah Datar Regency is located around the foot of Mount Merapi, Mount Singgalang, and Mount Sago, and is also enriched with 25 rivers. Lake Singkarak, which is quite large, is part of the Tanah Datar Regency area, which is located in Batipuh Selatan and Rambat Districts.

Tanah Datar District consists of 14 sub-districts, namely X Koto District, Batipuh District, South Batipuh District, Pariangan District, Rambat District, Lima Kaum District, Padang Ganting District, North Lintau Buo District, Sungayang District, Tarab River District, Salimpaung District, and Districts Tanjung Baru. 3 (three) Districts located at an altitude between 750 s.d. 1000 meters above sea level, namely X Koto, Salimpaung, and Tanjung Baru Districts. Meanwhile, the other four Districts, namely Lima Kaum, Tanjung Emas, Padang Ganting, and Tarab River Districts, are located at an altitude of 450 s.d. 550 meters above sea level. Meanwhile, 7 more Districts are located at varying heights, for example, Lintau Buo District, which is located at an altitude between 200 s.d. 750 meters above sea level.

The capital of Tanah Datar Regency is in Batusangkar; the unique thing is that Batusangkar City is on the border of three sub-districts, namely Lima Kaum District, Tanjung Emas District, and Tarab River District. Meanwhile, the center of government is in Tanjung Emas District or to be precise in Nagari Pagaruyung. Meanwhile, the center of government is in Tanjung Emas District or to be precise in Nagari Pagaruyung. The city of Batusangkar is better known as the City of Culture because, in Tanah Datar Regency, there are many relics and inscriptions, especially the relics of the Basa Pagaruyung Palace, which is the center of the Minangkabau Kingdom.

Meanwhile, in terms of population, based on the projection results, the population in Luhak Tanah Datar, from now on referred to as Tanah Datar Regency, in 2016 reached 345,700 people scattered throughout the village or all jorong with a population growth rate of $0.25 \%$. The livelihood systems of local communities are very diverse, such as working in agriculture and livestock, the mining sector, and the services sector.

In terms of regional governance affairs, based on Law of the Republic of Indonesia Number 23 of 2014 concerning Regional Government. In Article 1 paragraph 2, Regional Government is the administration of government affairs by the regional government and regional people's representative council according to the principle of autonomy and duty of assistance with the broadest autonomy principle in the system and principles of the Unitary State of the Republic of Indonesia as referred to in the Constitution of the Republic of Indonesia. Indonesia 1945. What is meant by autonomous regions according to this law is stated in paragraph 6 that Regional Autonomy is the right, authority, and obligation of an autonomous region to regulate and administer Government Affairs and the interests of local communities in the system of the Unitary State of the Republic of Indonesia.

Based on this law, it is stated that regions are entitled to their respective regions in order to achieve the welfare of their people, including adjusting the form and structure of the village government based on the origin and sociocultural conditions of the local community. Following up on this, the West Sumatra Provincial Regulation Number: 9 of 2000 concerning Basic Provisions for Nagari Government was issued. The Nagari Government System is seen as useful in order to create religious and cultural resilience based on the traditions and socio-culture of the people of West Sumatra, which are democratic and aspirational and in order to achieve community independence, participation, and creativity. Nagari type is a classification of nagari, which is divided into rural areas and urban areas according to existing conditions and categories. Local Environment Unit (SLS) is a local environment under the Nagari. The term SLS usually differs between regions, such as hamlet, neighborhood, and jorong or alley.

In the social structure of the Minangkabau community, Minangkabau customs continue to develop with the leader of the head in the Kerapatan Adat Nagari (KAN) forum. In 1947, a Supreme Council of Minangkabau Natural Adat Density (MTKAAM) was grown (at the beginning of Indonesian Independence). In 1966, the New Order Government of the Republic of Indonesia was also cultivating, an organization of Minangkabau Nature densities that raised funds, preserved and fostered Minangkabau customs. Each Luhak has a KAN in each of their nagas, such as in Luhak Tanah Datar: Nagari Tigo Koto. Meanwhile, LKAAM has its roots in the province and has roots in Nagari-nagari (KAN). In 1983 the Nagari Adat Density was established and regulated by a West Sumatra Regional Regulation.

Based on the results of the research, the things found in the field are related to the potential support for social integration in the Minangkabau community in Luhak Tanah Datar, the first is in terms of kinship and organizational systems. The Minangkabau conventional system was first coined by two brothers, Datuk Ketumanggungan and Datuk Perpatih Nan Sebatang. Datuk Ketumanggungan inherited the aristocratic Koto Piliang customary system, while Datuk Perpatih inherited the egalitarian Bodi Caniago customary system. In its journey, these two customary systems, known as kelarasan, complement each other and form the system of the Minangkabau community. With the ethnic division of the Minangkabau people, the surrounding community feels they come from the same descent because they feel they are in one family so that they belong to each other and identify with each other as part of the Minangkabau community group even wherever they are. Also, three pillars build and maintain the integrity of culture and customs. They are religious scholars, clever-clever, and ninik mamak, known as Tungku Tigo Sajarangan. The three of them complement each other and work hand in hand in the same position in height. In a democratic and egalitarian Minangkabau society, all community affairs are discussed by these three elements by consensus. 
Likewise with those found in the Minangkabau community in Luhak Tanah Datar.

The kinship system adopted by the Minangkabau community is a matrelineal kinship system. In this society the role of bundo kanduang is significant. Bundo kanduang in the Minangkabau community is very important, and this applies to every Minangkabau community, including those in Luhak Tanah Datar. This condition can be seen by the active participation of the Kanduang Bundo in organizing social activities such as socialization about customs, Minangkabau women's personalities and so on.

Like in other Luhak, Tanah Datar Luhak also has a tradition of giving titles or gala. Reference [10] explains that the title Datuak is a title given to the leader of a tribe or korong in the area of the Minangkabau ethnic population. The title of datuak is also called the title of sako in Minangkabau. Apart from the title datuak there is a title given to a man in Minangkabau on his wedding day and since then it has been advisable for anyone to call this man by his title. So it is no longer by calling his first name, as a form of respect for people who have grown up.

The researchers also found this condition by the results of observations when interviewing one of the settlers' houses in the Kanagarian. Where the husband of one of the research informants was not even called by his first name but the title or gala he received since he married his wife in Kanagarian Tigo Koto by his wife's family. Thus a gala must exist for every man who marries a Minangkabau woman; otherwise, the person is considered uncivilized. For this reason, Minangkabau men or those from outside (amalgamation) when they want to marry Minangkabau women must be given a gala.

The tolerance of the Minangkabau community in Luhak Tanah Datar is also the same as other luhak. This is confirmed by giving gala to immigrants (men who want to marry Minangkabau women) who are given at marriage or after marriage by traditional leaders to the groom.

The second factor is the religious system, in terms of religion, Luhak Tanah Datar as luhak nan tuo as the beginning of the Minangkabau natural area is not much different from the religious systems that exist in other luhak. In every luhak uphold syarak (religion). The community is highly upholding religious values because, for this community, religion is its identity as the Minangkabau community.

The existence of religion makes this community feel a unity among fellow adherents, especially because religion and customs in this community go hand in hand and complement each other. What is in the religious advice is characteristic of Minangkabau customs. In a community that believes in sacred things, religion and ideology are seen by members of society as an absolute goal worth dying for, meaning that the adherents of these beliefs are ready to sacrifice their lives in order to defend the ideology they believe in. Religion will become a spirit of integration if each of its adherents has the same viewpoint of that belief. However, it also triggers disintegration if the religion is divided into different schools (sectarian).
Third, the language system. Minangkabau language is very strong in this area, this is as the researchers found in the field. Where every community there uses and communicates using the Minangkabau language. And if there are Minangkabau people who do not use their local language in their daily conversations, they are considered arrogant. They interact using the Minangkabau language, be it when joking, in the market, at the shop to certain occasions also using the Minangkabau language in communicating, according to the community, it can bring distant people closer, create a lasting atmosphere, feel one family, and each other. have another one. Through this language, each individual defines himself as part of the Minangkabau community. In addition, Minangkabau paraphrases and petitihs also teach how to communicate karma. This is stated in the terms kato nan ampek, namely kato mandaki, kato manurun, kato mandata, and kato malereang. Those tips are taught how to talk to younger, older, equal and respected people.

Fourth, art. Talking about Minangkabau culture, of course, cannot be separated from its unique and distinctive art. Through this artistic activity, of course, it can foster togetherness between one another. Starting from the dances, randai, pecak silat, traditional clothes, folk songs, wedding customs to traditional dishes which are symbols of Minangkabau culture. With these characteristics, the Minangkabau people are proud to be part of this culture. And through these artistic activities, of course, it is also able to strengthen the relationship between people. One of them is the Pagaruyuang festival which is held once a year. In this festival, all Bundo Kanduang participate in enlivening the event, one of the activities is eating Bajamba. This activity was attended by all elements of society so that many immigrants visited, including Malaysians, Indians and so on.

\section{B. Discussion}

Culture is a social unifier that can be in the form of social wealth, including knowledge, beliefs, customs, skills, values, attitudes, behavior, and ways of thinking of social groups that are acquired by members of the community. The cultural value system is the highest level and the most abstract of customs. This is because cultural values are concepts about something that is in the minds of most of the people, which they consider valuable, valuable, and essential in life so that they can function as a guideline that gives direction and orientation to the lives of these community members.

Studying the elements contained in culture is very important to understanding human culture. C. Kluckhon (1953), in his book entitled Universal Categories of Culture, also describes various cultural elements. Divide the culture found in all nations of the world from simple cultural systems such as rural communities to complex cultural systems such as urban communities. According reference to [11], the term universal shows that cultural elements are universal and can be found in the cultures of all nations spread throughout the world.

Talking about the language system as an element of culture, of course every luhak in the Minangkabau natural area of West Sumatra has its own dialect. As is the case in Luhak Tanah Datar, which has its own Minangkabau 
style, but the methods remain the same as the Minangkabau language. In anthropology, the study of language is called linguistic anthropology. According to Keesing, the human ability to build cultural traditions, create an understanding of social phenomena expressed symbolically, and pass it on to future generations is very dependent on language. Thus, language occupies an important portion in the analysis of human culture. Language is a form of culture that humans use to communicate or interact with each other, either verbally, in writing or in sign language.

Smooth and good communication has the potential to strengthen human relationships. For this reason, the Minangkabau people are very concerned about how to communicate properly and correctly with each other, this is stated in the terms of kato nan ampek, namely kato mandaki, kato manurun, kato mandata, and kato malereang. The petitih words were taught how to talk to younger, older, equal and kato malereang. the word slope is our speech system towards people we respect. Almost the same as kato mandaki which is also aimed at older people, but the difference is that kato malereang is used for people we respect such as in-laws and talks between traditional, religious and leaders. In kato malereang, the language used is the language according to the situation. In Minangkabau, when we talk to traditional leaders, they usually use figurative words and words that are full of meaning. In the adage of the customary adage, internalize how to be polite in communicating. If each community practices this petitih divide, then divisions can be minimized. Besides that, the existence of this regional language is also able to strengthen the solidarity of the community, this is because each of them feels one fate, one family, especially when they are far from home (overseas).

This, as stated by reference [12] regarding the elements of language or the human symbol system orally or in writing for communication, is a description of the most important features of the language spoken by the tribe concerned along with the variations of that language. The salient features of these tribal languages can be described by comparing them in the world classifications of languages into families, sub-families, families and subfamilies. According to Koentjaraningrat, determining the boundaries of the spread of a language is not easy because the border areas where individuals live are very intensive places to interact so that the process of mutually influencing language development often occurs. In Minangkabau society, language is fundamental in its culture; this is used as a collective identity so that each individual classifies himself as part of the community.

Second, the knowledge system is everything that humans know about objects, properties, conditions, and expectations. One of them is customary law which is an extension of the existence of a way of behaving that is carried out by an individual which if that method is carried out continuously; a habit will form which if the habit is followed by individuals in a community group so that the community group also following these habits, then these habits will become a custom of the community group. Then gradually, the community group made this custom as a custom that should be used by members of the local community, so that what was meant by customary law that was accepted and had to be implemented by the community concerned was born. In general, in the traditional Indonesian legal system, there are unwritten laws as well as laws that are not codified in a statute book. This unwritten law is called customary law, which is a synonym for the meaning of customary law [13].

Customary law is an unwritten rule or pattern of community behavior that is sanctioned if it breaks it in order to create peace in society. Meanwhile, according to Prof. Dr. C. Van Vollenhoven, namely the rules of conduct that apply to indigenous peoples and foreign easterners, on the one hand, have sanctions (hence the word law) and, on the other hand, are not codified (hence the word adat). Meanwhile, according to Prof. Dr. B. Ter Haar Bzn who became a Professor at the College of Law (RHS-Rechts Hoge School) in Jakarta, customary law is the whole rule that is incarnated from the decisions of legal functionaries (in the broadest sense) who have authority and have influence and influence. Which in the implementation is automatically enforced and obeyed wholeheartedly.

This law is used as a life principle which is used as a guideline in social life to create security, order and creating a virtuous and noble society, "talatak is something that seems to be, lamak in the katuju crew in urang,"talatak sesuatu pada tampeknyo, lamak di awak katuju di urang, "padi masak jaguang maupiah, taranak bakambang biak, bapak kayo mandeh batuah, mamak di hormati urang". With this rule, the local community follows the prevailing rules in society so that harmony can be created even though conflict is inevitable. However, even if the conflict occurs, this can be done in solving the problem following the customary provisions that apply in the community.

Third, the kinship system is an essential part of the social structure. The kinship system is a system of calculating lineages based on marital relations and blood relations. It can also be said that kinship is social units consisting of several families that are related by blood and marital relations. Several kinship systems are owned/lived by the people in Indonesia, namely: the bilateral kinship system is a kinship system that calculates the lineage of two parties, namely from the father and mother in a balanced / joint manner. Unilateral kinship system, is a kinship system that calculates the lineage of one party, namely from the mother only which is called the matrilineal system or from the father's side which is called the patrilineal system. Takineal kinship system, is a kinship system that calculates the lineage from the father's side and the mother's side alternately, or it can be said to calculate the partial lineage from the father's side and part of the mother's side.

Similar to the kinship and organizational systems in Luhak Fifty Cities and Luhak Agam, Luhak Tanah Datar also has a matrilineal kinship system like other Minangkabau communities. Based on the findings in the field, the people in Luhak Tanah Datar consist of various ethnicities, consisting of Batak, Javanese, Indian, and Minangkabau ethnic groups. As the researchers found in the field, there are several ethnic groups and adherents of 
religions other than Islam, the Minangkabau people who are there, of course, use a matrilineal kinship system as evidenced by the arrival of the men to the women's house, this condition is going well. With this common lineage, local people feel like one family, which is fostered with exclusive relationships among each other. Likewise, the lineage of the Minangkabau people in Luhak Tanah Datar, like in other luhak, of course, this community originated from the spread of cultural customs brought by Datuak Parpatiah Nan Sabatang and Datuak Katumangungan.

This matrelineal system is a kinship system of the Minangkabau community, which makes the people responsible for each other and have family relationships. With a good feeling like this, it allows harmony in social life. Besides the matrilineal system and the same lineage, the Minangkabau people, especially in Luhak, also have three pillars in the structure of their society. In this society, there are elements of religious scholars, clever cleverness, and ninik mamak, known as Tungku Tigo Sajarangan, which functions in managing community affairs through deliberation and consensus.

\section{CONCLUSION}

The socio-cultural elements in the Minangkabau community that have the opportunity to integrate the community are located in the customary philosophical system based on the teachings of the Islamic religion, the Minangkabau language which unites each community, traditional arts, kinship systems, and customs which are still strong in the life of the community. This is also supported because Luhak Tanah Datar is the first or oldest luhak known as luhak nan tuo.

\section{ACKNOWLEDGMENT}

Our gratitude goes to the Dean of the Faculty of Social Sciences, Manado State University, who has provided support in writing this article. We also do not forget to thank all citizens of Tanah Datar District, especially in Kanagarian Tigo Koto, who have been willing to participate in this research.

\section{REFERENCES}

[1] D. Hann, D. Nash, and E. Heery, 'Workplace conflict resolution in Wales: The unexpected prevalence of alternative dispute resolution', Econ. Ind. Democr., vol. 40, no. 3, pp. 776-802, 2019.
[2] P. F. Diehl and P. Regan, 'The interdependence of conflict management attempts', Confl. Manag. Peace Sci., vol. 32, no. 1, pp. 99-107, 2015.

[3] T. Rejekiningsih, 'Law Awareness Forming Strategies to Reinforce The Principles of Social Function of Land Rights Within The Moral Dimension of Citizenship', Procedia-Social Behav. Sci., vol. 211, pp. 69-74, 2015.

[4] R. Porat, E. Halperin, and D. Bar-Tal, 'The effect of sociopsychological barriers on the processing of new information about peace opportunities', $J$. Conflict Resolut., vol. 59, no. 1, pp. 93-119, 2015.

[5] I. Lavi, D. Canetti, K. Sharvit, D. Bar-Tal, and S. E. Hobfoll, 'Protected by ethos in a protracted conflict? A comparative study among Israelis and Palestinians in the West Bank, Gaza, and East Jerusalem', J. Conflict Resolut., vol. 58, no. 1, pp. 68-92, 2014.

[6] T. C. Prieto-Remón, J. R. Cobo-Benita, I. OrtizMarcos, and A. Uruburu, 'Conflict resolution to project performance', Procedia-Social Behav. Sci., vol. 194, no. 7, pp. 155-164, 2015.

[7] L. Lindayanti and Z. Zaiyardam, 'Konflik Dan Integrasi Dalam Masyarakat Plural: Jambi 19702012', Paramita Hist. Stud. J., vol. 25, no. 2, pp. 169-184, 2016.

[8] R. Retnowati, 'Agama, Konflik, dan Integrasi Sosial (Integrasi Sosial Pasca Konflik, Situbondo)', Anal. J. Soc. Sci. Relig., vol. 21, no. 2, pp. 189-200, 2014.

[9] S. Fathimah and F. Eriyanti, 'Mapping factors that support social integration of minangkabau community in Luhak Agam', in International Conference on Education, Islamic Studies and Social Sciences Research, 2018, pp. 727-733.

[10] A. Amrizal, 'Asal Usul dan Makna Nama Gelar Datuak di Nagari Nan Tujuah Kecamatan Palupuh Kabupaten Agam', J. Elektron. WACANA Etn., vol. 2, no. 2, pp. 73-94, 2011.

[11] Koentjaraningrat, "'Manusia dan Kebudayaan Di Indonesia", Djambatan, 2007.

[12] C. Kluckhohn and K. AL, 'Anthropology today', 1953.

[13] S. Soekanto, Kedudukan dan Peranan Hukum Adat di Indonesia. Kurnia Esa, 1982. 